\title{
A Indústria Têxtil, suas Trabalhadoras e os Censos da População de Minas Gerais do Século XIX
}

\author{
uma Reavaliação*1
}

\section{The Textile Industry, Women's Work, and the $1^{\text {th }}$ Century Censuses of the Population of Minas Gerais}

\section{a new appraisal}

Concessa vaz de MACEDO

Departamento de Ciências Econômicas da Universidade Federal de Minas Gerais Economista, Doutora em História Econômica pela Universidade de São Paulo Faculdade de Ciências Econômicas, Rua Curitiba, 832 - 30170-120 - Belo Horizonte, MG E-mail: concessa@cedeplar.ufmg.br

RESUMO O objetivo deste estudo é reavaliar as informações sobre as ocupações dos habitantes de Minas Gerais, de modo a retificar o lugar de destaque da indústria têxtil na economia da Província. As evidências aqui apresentadas são inéditas e resultaram de um novo esquema de classificação das ocupações originárias de dois registros oficiais, a sa-

\footnotetext{
Artigo recebido em 12/08/2005. Aprovado em 20/12/2005.

Este artigo deriva da pesquisa desta autora intitulada "Trabalho Feminino e suas Técnicas — Processo de Trabalho e Organização da Indústria de Fios e Tecidos em Minas Gerais no Século XIX”, concluída em dezembro de 2004. Departamento de Ciências Econômicas da UFMG e Centro de Desenvolvimento e Planejamento Regional - Cedeplar. Apoio financeiro da Fundação de Amparo e Pesquisa de Minas Gerais — FAPEMIG.
} 
ber, as Listas Nominativas da População de Minas Gerais de 1831-32 e o Recenseamento Geral do Império de 1872. Com base nessa classificação, pôde-se recompor a estrutura ocupacional da população e, então, confirmar e reabilitar a importância da indústria têxtil, e de suas mulheres trabalhadoras, na economia do período.

Palavras-chave Mulheres, Indústria Têxtil, História Econômica

ABSTRACT The aim of this paper is to reconsider the information about occupation of the population of Minas Gerais, in order to rectify the prominence of the textile industry in its economy. The evidence presented here is original and has been derived from a new classificatory scheme based on data provided by two official records, namely the Nominative Lists of the Population of Minas Gerais for the years 1831-32 and the 1872 General Census of the Empire. On the basis of such scheme, it was then possible to reconstruct the occupational structure of the population, and therefore reinforce as well as restore the importance of textiles, and of female labour, in the economy of the time.

Key words Women, textile industry, Economic History

\section{Introdução}

\subsection{Do Objeto}

O presente artigo consiste numa reavaliação dos dados de caráter censitário disponíveis para o século XIX mineiro, com vistas a se apreender o perfil econômico da Província e a importância relativa de sua produção artesanal de fios e tecidos - a indústria têxtil prevalecente.

O primeiro conjunto de dados está contido nas Listas Nominativas da População de Minas Gerais de 1831-32, um censo provincial bastante expressivo pela abertura de suas informações. O segundo conjunto consta do Recenseamento Geral do Império de 1872, um registro mais agregado e de menor cobertura que o primeiro no que respeita as ocupações dos habitantes.

Esses dois arrolamentos da população são obviamente conhecidos. O primeiro, em especial, tem servido de base para estudos recentes sobre Minas Gerais, focando-se, sobretudo, nas vilas, cidades, distritos e atividades econômicas específicas da Província. Para a sua totalidade, contudo, faltam pesquisas sistemáticas desde que essas listas foram primeiramente abordadas na década de 1980. O Censo de 1872 também carece de reavaliação, em particular no que se refere ao tema aqui investigado e à luz das listas que o precederam, hoje disponíveis de forma ampliada. 
O fundamental nesses dois documentos é que ambos fornecem, com gradações distintas, uma enumeração oficial da população da Província com fatos e condições sociais expressos em termos numéricos, o que favorece o seu conhecimento sob o ponto de vista de sua população, indústria, agricultura, administração, comércio, força militar, etc., em dois momentos de um período histórico estruturado sobre a mesma base - a escravidão. Mesmo não sendo esses censos imediatamente compatíveis, em função de suas diferenças estruturais e da composição das variáveis registradas, e mesmo não tendo sido acompanhados de instruções sobre os métodos, definições e conceitos utilizados, é possível estabelecer-se um esquema uniforme e comum de classificação de seus dados de modo a se detectar, em cada um dos conjuntos, o perfil econômico da Província e o lugar ocupado pela indústria têxtil na realidade do século XIX. Nisto consiste, em essência, o objeto do estudo ora apresentado.

Ambos os arrolamentos traduzem, a posteriori e em dois pontos distantes no tempo, as transformações ocorridas na economia mineira desde o declínio de sua atividade mineradora, em torno da qual gravitavam todas as demais atividades. Embora fundamentais para a manutenção da ordem social vigente, essas mudanças foram antes arranjos circunstanciais que alterações, desde a base, capazes de abalar o estado de coisas prevalecente. Modificaram-se as feições da Província, não sua estrutura básica, a qual só viria a ser subvertida no século XX, a despeito de que seus elementos motores já estivessem atuando nas três últimas décadas dos Oitocentos. As mudanças pontuais, embora fecundas, do final do século XIX, aquelas relativas às novas bases em que a dinâmica econômica viria a se assentar - o capitalismo e suas relações de produção assalariadas - , hão de ser empírica e teoricamente examinadas em limites próprios. Numa ordem social regida pela escravidão, as experiências das primeiras fábricas têxteis, plantadas em solo rural, aparecem como excrescências em total desarmonia com um mundo de há muito edificado, cujas vigas apenas trincavam.

A fábrica - "o lócus privilegiado de atuação da burguesia", de transformações que revolucionariam "o processo produtivo, as relações de produção e os sistemas de trocas entre os setores da economia até então vigentes", 2 bem como o sistema de valores correspondentes à velha ordem social - representa uma solução de continuidade formada tanto por contingências internas quanto externas. Representa, em suma, um rompimento de relações sociais sobre as quais se assentava a economia

2 Em tese de grande envergadura intitulada "A Modernização Capitalista em Minas Gerais - A Formação do Operariado Industrial e de uma Cosmovisão" e publicada como GIROLETTI, Domingues. Fábrica, Convento, Disciplina. Belo Horizonte: Imprensa Oficial, 1991. 
de Minas Gerais. As relações que Ihes sucederam, cujos determinantes são de natureza diversa, fogem do escopo da presente investigação. ${ }^{3}$

Esse entendimento do processo histórico demarca o período abrangido por este estudo, qual seja, os anos do Dezenove mineiro que se estendem até o fim da escravidão, em 1888.

\subsection{Das Fontes e sua Abordagem}

As Listas Nominativas de 1831-32 constituem o ponto de partida desta análise. Tendo vindo à tona pelo trabalho pioneiro do historiador Douglas Cole Libby, essas Listas já indicavam, a partir de uma amostra de 26 distritos selecionados, o lugar de vanguarda ocupado pela indústria têxtil no conjunto do setor de transformação. ${ }^{4}$ Ainda que mantendo um posto de importância na economia, o autor observou sua tendência para o declínio, no confronto com os dados do Censo de 1872. Estes resultados não conflitam com os que serão apresentados neste estudo. Contudo, dispondo-se hoje de uma amostra amplificada, abrangendo 231 distritos, a possibilidade de se classificar os dados, sob novos e diferenciados critérios, mostrou-se viável e apropriada. Ao invés de se adaptar, de forma linear, as informações nominadas nas Listas de 1831-32 ao esquema pré-estabelecido no Censo de 1872 - expediente utilizado por Cole Libby -, optou-se, aqui, por elaborar uma classificação nos moldes de uma "setorização básica", o que fora rejeitado pelo historiador como um anacronismo - algo inadequado à realidade da economia mineira do século XIX.

Entende-se que uma "setorização básica" aplica-se a realidades econômicas diversas, desde que alcançado um certo nível de produtividade e de desenvolvimento. ${ }^{5}$

Com efeito, e em particular, os excedentes produzidos e comercializados pela província mineira ao longo do século XIX — evidências fartamente documentadas e divulgadas - constituem fortes indícios da elevada produtividade da economia, além de contrariarem as teses que advogam a decadência de Minas Gerais, após o declínio da mineração. Além do mais, sendo as trocas de caráter regular e constante, realizando-se entre regiões, cidades e vilas do território mineiro, sem se desprezar outras províncias, uma extensa divisão do trabalho haveria de preva-

3 Na Dissertação de Mestrado referenciada a seguir, a autora deste artigo investigou o trabalho feminino na Indústria Brasileira e seus determinantes, através dos Censos do século XX. Vide MACEDO, Concessa Vaz de. Diferenciação Ocupacional e Salarial do Operariado Feminino "vis-à-vis" O Masculino na Indústria Brasileira. Belo Horizonte: Cedeplar/UFMG, 1985.

4 Tese de doutoramento intitulada "População e Mão-de-Obra na Província de Minas Gerais (1830-1889)" e publicada como LIBBY, Douglas Cole. Transformação e Trabalho em uma Economia Escravista - Minas Gerais no Século XIX. São Paulo: Brasiliense, 1988.

5 Vide, a esse respeito, a discussão feita por Marx sobre "a divisão do trabalho na sociedade". Em MARX, Karl. O Capital. England: Penguin Books, 1986, vol.1, cap.14, s.4, p.470-480 e p.471, n.25. 
lecer - condição necessária para a própria existência de trocas. Dito de outro modo, a economia mineira apresentava um grau relativamente elevado de especialização de sua força de trabalho, o que, na realidade, manifestava-se na diversidade dos produtos vendidos. Esta especialização ocupacional vem a ser, aliás, referendada tanto pelas Listas de 183132 quanto pelo Censo de 1872. Desta forma, guardados os critérios, conceitos e definições precisos, uma classificação construída nos moldes de uma "setorização básica" da economia pode se transformar em um recurso didático, em uma ferramenta útil, capaz de instruir sobre a realidade Oitocentista. Além disso, o enorme conjunto de registros numéricos associados às ocupações ou grupo de ocupações disponível permite uma avaliação mais precisa se submetido a uma classificação dessa natureza. Concluindo, é na aceitação e no uso desse instrumento referencial de classificação que reside a diferença entre esta nova abordagem e aquela adotada por Cole Libby em 1988.

Quanto ao segundo conjunto de informações - o Recenseamento Geral do Império de 1872 - , este será classificado de acordo com os mesmos critérios formulados para as Listas Nominativas.

Uma classificação das ocupações desse Censo encontra-se nas Estatísticas Históricas do Brasil do IBGE, reeditadas em 1990. Nesta classificação, não há indústria têxtil. As ocupações femininas registradas originalmente no Censo foram retiradas do "grupo ativo", por terem sido compreendidas como "duvidosas" ou "mal definidas ou indefinidas". Este assunto será retomado e detalhado adiante neste artigo. Contudo, essa omissão, e mesmo violação de informação, sugere a necessidade de se esclarecer o significado e a natureza da indústria têxtil do século XIX e do trabalho a ela correspondente - objeto central deste estudo —, como subsídio à análise aqui pretendida.

\subsection{Da Indústria Têxtil e suas Trabalhadoras}

A indústria têxtil que predominou em Minas Gerais no século XIX era eminentemente artesanal em sua base técnica de produção — o fundamento de qualquer ofício. Essa indústria, através da qual fibras naturais transformavam-se em fios e estes em tecidos, assentava-se no trabalho das mulheres, que dominavam e controlavam os métodos e técnicas de produção específicos, bem como os materiais necessários e o produto final ou acabado. Desse saber peculiar, que Ihes era próprio, dependia todo o processo de trabalho desenvolvido, de forma autônoma e independente. E porque esse saber Ihes pertencia, só por elas haveria de ser repassado, através do "aprender fazendo", um processo de aprendizado ou forma característica de transmissão do conhecimento artesanal, comum a todos os ofícios e onde quer que estes fossem executados. 0 "aprender fazendo" era, pois, a forma de aprendizado inerente ao traba- 
Iho artesanal, não podendo, portanto, ser dispensada. Por essa via, e somente por ela, produzia-se um artesão de ofício - um produtor de artes industriais.

O caráter artesanal do trabalho não guarda correspondência alguma com o "locus" de produção, nem é por ele determinado. ${ }^{6} \mathrm{Na}$ casa ou na oficina, no gineceu dos domínios senhoriais, nos canteiros de obra ou ainda em caminhos itinerantes, o artesão prosseguia sendo o produtor cujo saber específico the pertencia. Dono de um conhecimento peculiar, hábil no manejo de implementos manuais mais ou menos complexos, repassava este saber da mesma forma que o havia recebido de outrem - pelo "aprender fazendo".

Ao longo do século XIX em Minas Gerais, a produção de fios e tecidos expandiu-se consideravelmente, tornando-se uma indústria cujos trabalhadores eram tipicamente mulheres. Estas, escravas ou não, eram as artesãs de seus ofícios - as "cardadeiras", "fiandeiras", "tecedeiras" e "tingideiras". A eventual reunião de escravas sob um mesmo teto e sob a vigilância de um feitor, em nada modifica o caráter artesanal de seu trabalho, antes corresponde às relações de dominação prevalecentes.

Essa indústria foi completa e erroneamente ignorada por aqueles que produziram as estatísticas exibidas nas edições do IBGE. Mesmo aqueles, como Cole Libby, que revelaram através das Listas Nominativas o lugar de destaque dessa atividade produtiva, não reconheceram suas trabalhadoras como agentes econômicos propriamente.

Com efeito, em tese desse historiador já mencionada anteriormente, a produção artesanal de fios e tecidos, sob o domínio das mulheres, aparece sob a denominação "indústria têxtil doméstica" ou "produção caseira", em oposição à "produção oficinal ou artesanal" ou "ofícios", predominantemente masculina. ${ }^{7}$ A produção artesanal equivale, para aquele, dadas as referidas denominações, à que se realiza na "pequena oficina", onde o período formal de aprendizagem era, supostamente, prevalecente. ${ }^{8}$ Alega também o autor, a propósito da aprendizagem, que "esse elemento básico da organização artesanal" era "dispensável" no recinto doméstico, onde as produtoras de fios e tecidos realizavam seu

6 Nas corporações de ofício das cidades medievais européias, a oficina do mestre era usualmente sua própria moradia. Por volta do século XVI, a indústria têxtil artesanal inglesa, antes sediada nas cidades "consentidas", inicia sua marcha para o campo. Em consequeência, o domicílio rural foi transformado em domicílio produtivo, onde seus artesãos, homens e mulheres dos ofícios de tecer e fiar, dividiam entre si a arte de produzir tecidos. O domicílio rural, transformado em unidade produtiva, assim permaneceu até ser desintegrado quando da revolução industrial inglesa. Vide MACEDO, Concessa Vaz de. As Mulheres, seus Ofícios e suas Técnicas - Processo de Trabalho nas Indústrias Têxteis Britânicas antes da Revolução Industrial. São Paulo: USP, 1996. (Tese de doutoramento, Departamento de História).

7 LIBBY, Douglas Cole. Transformação e Trabalho em uma Economia Escravista, p.17.

8 Questiona-se, aqui, a existência de organizações artesanais em Minas Gerais no século XIX. Segundo Gama, as corporações de ofício no Brasil foram inexpressivas face às suas congêneres européias, terminando por serem totalmente abolidas pela Constituição do Império de 1824. Vide GAMA, Ruy. A Tecnologia e o Trabalho na História. São Paulo: Nobel/EDUSP, 1987, p.106-107. 
trabalho. Isto posto, a economia mineira achava-se, no seu entender, dividida em dois setores distintos, a saber, um "doméstico ou caseiro", nas mãos das mulheres, e outro "oficinal ou artesanal", nas mãos dos homens. ${ }^{9}$

Diferentemente de Libby, e com base na concepção inicialmente sustentada, essa indústria será aqui designada pelas seguintes expressões alternativas — "produção de fios e tecidos" ou "indústria têxtil" —, acompanhadas ou não de seu atributo "artesanal" - um dado. Ocasionalmente, as expressões "indústria familiar" e "indústria domiciliar" serão utilizadas como categorias analíticas, ou seja, para indicar a transformação do domicílio em unidade produtiva (Vide nota 5).

As Listas Nominativas de 1831-32 constituem objeto de discussão a seguir. Alguns pressupostos teóricos/históricos fundamentam a metodologia elaborada para o tratamento dos dados de ocupação dos habitantes. Estes pressupostos são simultaneamente evidências e hipóteses sobre a realidade de Minas Gerais até a década de 1880 e referem-se, principalmente, aos seguintes aspectos: a) ao caráter escravista da economia mineira, a despeito do imenso contingente livre da população; b) à transferência de recursos para atividades alternativas à mineração; e c) à emergência da indústria têxtil domiciliar, predominantemente feminina, entre aquelas alternativas.

\section{Fundamento histórico/teórico para o estudo das listas nomi- nativas da população de Minas Gerais de 1831-32}

Foi na década de 1980 que as Listas Nominativas foram localizadas no Arquivo Público Mineiro servindo de base para novas interpretações sobre o século XIX, as quais se contrapunham às teses até então assumidas que estabeleciam uma correlação positiva entre decadência da mineração e decadência da Província em si, sobretudo na versão de Furtado (1976). ${ }^{10}$

Já em 1980, em sua tese de doutoramento sugestivamente denominada Growing in Silence, Martins antecipava que Minas experimentara um grande dinamismo, e não um declínio em sua atividade econômica, após a decadência do ouro. O ponto central de seu argumento fundavase na observada "entrada líqüida" de escravos em Minas Gerais nas décadas que sucederam ao esgotamento da mineração, o que sugeria a existência de algum setor dinâmico interno que estivesse compensando esse declínio com base na imigração de cativos.

9 LIBBY, Douglas Cole. Transformação e Trabalho em uma Economia Escravista.

10 FURTADO, Celso. Formação Econômica do Brasil. São Paulo: Nacional, 1976. 
Com efeito, enquanto escrava a força de trabalho haveria de ser empregada produtivamente de modo a continuar criando riqueza e lucro para seus donos.

Os novos documentos que surgiram a seguir promoveram pesquisas que viriam referendar o reverso da decadência, ou seja, o suposto dinamismo econômico de Minas na primeira metade do século XIX.

Sob a coordenação da pesquisadora Clotilde de Andrade Paiva, do Cedeplar/UFMG, um considerável trabalho de equipe transcreveu as informações manuscritas das Listas Nominativas de Distritos de Paz de Minas Gerais e armazenou-as em um Banco de Dados. A tese de doutoramento de Paiva veio a seguir (1996), a qual procurava essencialmente articular as evidências de um significativo crescimento populacional com um ativo comércio interno à Província e, por esse meio, sustentar a tese, já em voga, do dinamismo econômico mineiro.

Tanto os achados de Martins quanto os de Paiva parecem antes sintomas ou manifestações das mudanças que se operavam na base produtiva, ou seja, fenômenos desencadeados por alterações que se produziam no chamado lado real da economia. Isso eqüivale à proposição de que à decadência do ouro sucedeu um deslocamento de recursos para atividades pré-existentes e já consolidadas, embora até então secundárias do ponto de vista dos grandes interesses econômicos prevalecentes. Essas atividades haveriam de ser aquelas aptas a se organizarem rapidamente de modo a evitar as perdas advindas da mineração em declínio e dos braços crescentemente ociosos dos escravos. Por outro lado, a atividade mercantil interna, engrandecida por Paiva, só poderia ser passível de existência se fundada numa estrutura produtiva diversificada, capaz tanto de sustentar uma população em crescimento quanto de produzir excedentes comercializáveis.

A agricultura teve papel crucial nesse processo. Condição necessária ao crescimento populacional, o cultivo da terra fazia-se com instrumentos individuais (enxadas, enxadões, foices, pás, facões etc.), quase meros prolongamentos de pés e mãos dos trabalhadores, e a esse caráter diminuto dos instrumentos haveria de corresponder um enorme contingente de escravos requeridos para um plantio promissor e factível. A alternativa agrícola implicava, sob tais condições, no continuado fluxo de escravos em direção à província mineira, que pode não ter sido a alternativa mais lucrativa, mas, aceitando o argumento de Kowarick, foi a solução encontrada "numa situação histórica em que seria impossível tentar a submissão em massa da população livre". ${ }^{11}$

11 KOWARICK, Lúcio. Trabalho e Vadiagem - A Origem do Trabalho Livre no Brasil. São Paulo: Brasiliense, 1987, p.41. 
Quanto à indústria têxtil, o século XIX é testemunho do vaivém das tropas de muares carregadas de tecidos e de algodão em rama destinados a diversas localidades de Minas, à Corte — sediada no Rio de Janeiro - e a outras plagas do sul do país. Eram tecidos grossos e resistentes de algodão, por vezes mesclados com lã — cobertas e cobertores, mantas e colchas etc. — vindos das mãos das "cardadeiras", "fiandeiras", "tecedeiras" e "tingideiras" que dominavam esses ofícios. O "locus" da produção era o domicílio — lugar de produção, reprodução e consumo, caracteristicamente.

A par do incessante movimento dos tropeiros, listas oficiais de exportações de produtos de Minas têm sido generosamente publicadas por quantos se interessam pela atividade mercantil do período (Martins, 1980 e 1983; Paula, 1983; Vaz, 1990; Chaves, 2001; Bergad, 2004; entre outros). Estas documentam de forma inequívoca o caráter de mercadoria dos tecidos produzidos, ou seja, produtos destinados à troca no âmbito e além das fronteiras territoriais da Província e, ressalte-se, em grandes quantidades ao longo do século.

Pretende-se, ao examinar as Listas Nominativas, destacar o lugar e a função da indústria produtora de fios e tecidos - a indústria têxtil. $\mathrm{O}$ argumento e a proposição fundamentais a esse respeito podem ser assim resumidos:

a indústria têxtil familiar pré-existente, definida como aquela voltada para e pertencente à família, é a base sobre a qual a indústria domiciliar iria se desenvolver. Sob a mesma base técnica de produção, a indústria familiar transformou-se em domiciliar, ou seja, centrada no domicílio enquanto "locus" de produção, reprodução e consumo, mas voltada para fora (para a troca) e não para dentro (para o uso) exclusivamente.

As 231 Listas Nominativas, informando 787 ocupações dos habitantes de Minas, foram classificadas conforme o procedimento que se expõe a seguir. ${ }^{12}$

\section{Procedimento conceitual para a utilização das informações sobre ocupação das listas nominativas da população de Minas Ge- rais de 1831-32}

Algum tipo de classificação é necessário se se deseja recompor a estrutura ocupacional de uma população qualquer. Não se pode realizar essa tarefa sem a contaminação dos métodos atuais de classificação, os quais, dando uma idéia do que é desejável, devem contudo ser usados

12 Banco de Dados do Núcleo de Pesquisa em História Econômica e Demografia Histórica. Cedeplar/UFMG 
com cautela e qualificação. Devem ser entendidos como instrumento de análise por aproximação, permitindo uma classificação acessível e compreensível, bem como flexível.

Uma estrutura ocupacional não pode ser, ademais, um arranjo meramente abstrato, desprovido de significado histórico, o que o impediria de ser uma expressão satisfatória de uma realidade determinada.

Isso posto, o esquema classificatório das ocupações foi elaborado à luz dos métodos atuais contidos nos Censos Demográfico e Industrial do Brasil (IBGE) e na Classificação Brasileira de Ocupações (C.B.O, Ministério do Trabalho). Uma publicação pertinente do Cambridge Group for the History of Population and Social Structure, editada por Wrigley (1972), também orientou esse esquema, em particular o estudo enriquecedor de Armstrong - The Use of Information about Occupation. Critérios e conceitos foram estabelecidos com base nessas fontes, sem desconsiderar as especificidades históricas do período analisado.

O caráter abstrato da estrutura ocupacional pôde ser atenuado utilizando-se das definições e/ou significados das ocupações trazidas à tona pelos viajantes estrangeiros investigados. ${ }^{13}$ Dicionários conceituados da Língua Portuguesa completaram as ausências, bem como pesquisas da própria autora relativas à indústria têxtil artesanal (1996).

As observações que se seguem visam ao melhor entendimento do termo ocupação - objeto e ponto de partida da classificação empreendida - além de delinearem os critérios e conceitos utilizados.

O agrupamento de uma população a partir de suas ocupações tem como objetivo conhecer os contornos econômicos de uma sociedade qualquer e as bases nas quais ela se assenta. De outra forma, permite descobrir as atividades e os agentes econômicos sobre os quais recai, primordialmente, uma sociedade.

Uma ocupação é ela própria um agrupamento, qual seja, de um conjunto de tarefas e operações realizadas por alguém e que resulta na obtenção de produtos e/ou serviços (C.B.O). Assim, por exemplo, uma fiandeira através de uma série de operações transforma a matéria-prima algodão, linho, seda, lã etc. - em fio, o produto final ou acabado que servirá a diversos fins, à produção de tecidos particularmente.

Quando uma sociedade está em foco, o objeto de estudo recai não sobre Maria, a fiandeira, mas sobre o conjunto das fiandeiras enquanto produtoras de fios, as quais, em conjunto, constituem uma categoria ou classe ocupacional. Trata-se, pois, de reconhecer o que é típico e geral e não o único e particular (Armstrong, 1972).

Várias categorias ocupacionais podem, por sua vez, ser agrupadas sob uma outra classificação mais abrangente. O conjunto das fiandeiras

13 "Glossário de Termos", Anexo 1, da pesquisa da autora supra citada 
e o conjunto das tecedeiras podem compor um agrupamento — um Ramo de Atividade - de acordo com a natureza e/ou função comuns a esses dois conjuntos (categorias) ocupacionais (Censos Demográficos do Brasil). No exemplo, podem integrar o Ramo de Atividade denominado Produção de Fios e Tecidos ou Indústria Têxtil, uma vez que ambas as categorias tipificam o conjunto de tarefas e operações que visam à transformação de matérias-primas têxteis (que servem para tecer) em fios e tecidos.

Na mesma linha de raciocínio, é possível agregar os vários Ramos de Atividade em grandes Setores Econômicos (Censo Industrial do Brasil), os quais devem corresponder, igualmente, ao que há de comum e essencial aos primeiros. Assim, a Produção de Fios e Tecidos integra o Setor Secundário da economia, este reunindo sob sua rubrica todos os Ramos de Atividade (e categorias ocupacionais) cuja função é transformar matérias-primas em produtos finais ou acabados. O Setor Secundário corresponde, pois, à Indústria propriamente dita.

Ao lado do Secundário erguem-se dois outros setores: o Setor Primário e o Setor Terciário. O primeiro, como o próprio nome sugere, reúne, em grande medida, o conjunto de atividades e de ocupações empenhadas na obtenção de produtos susceptíveis de serem transformados, pela indústria, em produtos finais. Tanto a Agricultura quanto a Criação de Animais pertencem a esse setor, bem como todas as atividades de extração, exploração e captura de elementos da natureza — fontes primordiais de matérias-primas para a indústria. O Setor Terciário, por seu turno, vem englobar o conjunto das atividades e das ocupações que não sendo parte direta do processo produtivo estão a ele ligadas cumprindo a função de distribuição (circulação) e de prestação de serviços pessoais, sociais e os concedidos pelo poder público.

Alicerçada nesses critérios, a classificação das ocupações torna-se um instrumento útil de análise histórica, ou seja, algo capaz de instruir sobre a realidade em questão. As noções de setor econômico, ramo de atividade e ocupação, como expostas, servem de guia para se detectar a forma de organização do trabalho social no interior da província mineira Oitocentista.

\section{Estrutura ocupacional da população de Minas Gerais segundo as listas nominativas de 1831-32}

Tanto as Listas Nominativas quanto o Recenseamento Geral de Império não esgotam a população da província de Minas da época dos levantamentos. As primeiras cobrem 231 dos 250 distritos que haviam respondido ao ofício do presidente da Província datado de agosto de 1831 (Paiva, 1996, p.49, n. 2). O segundo deixa de cobrir 14 das 370 
paróquias então existentes, o que, segundo Paiva e Martins, "significa uma omissão inferior a 4\%". ${ }^{14}$ Mais relevante a ser registrado para o assunto sob investigação é o enorme percentual de habitantes "Sem Informação" e "Sem Profissão" em cada arrolamento respectivamente. Nas Listas, esse percentual gira em torno de 60\% dos declarantes, enquanto no Censo Geral foram 36\% os que se designaram "Sem Profissão".

Não é o objetivo deste estudo analisar o destino desse enorme contingente da população de Minas desprovido de alguma ocupação e/ou não informante a esse respeito. Há uma vasta literatura sobre o tema, bastando recordar os contundentes estudos de Laura de Mello e Souza e de Maria Sylvia de Carvalho Franco (1990 e 1997). O importante a ressaltar, contudo, é que tal dimensão de desvalidos constitui um claro indício da ausência de forças na economia mineira capazes de incluir uma grande parcela de seus habitantes. Neste estudo, examinam-se os dados de ocupação lançados naqueles dois documentos, os quais dizem respeito a um número não menos expressivo de habitantes - 40\% e $60 \%$ respectivamente - envolvidos em cerca de 800 ocupações, no caso das Listas Nominativas.

Com efeito, dos 149.294 habitantes ocupados em 1831-32 somente 8\% nomearam de maneira imprecisa e/ou incompreensível suas ocupações (vide Resíduo Ocupacional, Tabela 1), tendo os majoritários 92\% designado funções específicas e especializadas, o que indica a existência de uma divisão social de trabalho aprofundada, condição necessária para o desenvolvimento de uma economia de caráter mercantil, ou seja, voltada para o comércio ou troca.

A Tabela 1 exibe a estrutura ocupacional da população na forma de sua distribuição (absoluta) pelos 16 Ramos de Atividades e os 3 Setores Econômicos estabelecidos. A taxa de participação total de cada ramo em cada setor consta da última coluna.

De modo a perceber o peso relativo de homens (livres e escravos) e mulheres (livres e escravas) em cada ramo de atividade/setor econômico, calculou-se a porcentagem da população total ocupada daquele ramo/ setor constituída por homens e por mulheres, segundo sua condição social (Tabela 2). Essas taxas indicam os redutos ocupacionais de homens e mulheres, ou seja, a acentuada demarcação das ocupações segundo o sexo do trabalhador e/ou prestador de serviços.

14 PAIVA, Clotilde de Andrade; MARTINS, Maria do Carmo Salazar. Notas sobre o Censo Brasileiro de 1872. ANAIS: // Seminário sobre a Economia Mineira. Diamantina: Cedeplar/FACE/UFMG, 1983, p.156. 
Tabela 1 - Composição da População Ocupada por Ramo de Atividade e Setor Econômico - Segundo o Sexo e a Condição Social - Minas Gerais - 1831-32

\begin{tabular}{|c|c|c|c|c|c|c|c|c|}
\hline \multirow{2}{*}{$\begin{array}{l}\text { Setor Econômico/ } \\
\text { Ramo de Atividade }\end{array}$} & \multicolumn{3}{|c|}{ Homens } & \multicolumn{3}{|c|}{ Mulheres } & \multirow{2}{*}{ Total } & \multirow{2}{*}{$\%^{3}$} \\
\hline & Livre & Escravo & Total & Livre & Escravo & Total & & \\
\hline Setor Primário & 34.797 & 18.965 & 53.762 & 3.655 & 1.203 & 4.858 & 58.620 & 100,0 \\
\hline Agricultura & 30.918 & 16.630 & 47.548 & 3.288 & 1.029 & 4.317 & 51.865 & 88,5 \\
\hline Atividades Extrativas & 3.120 & 2.053 & 5.173 & 293 & 171 & 464 & 5.637 & 9,6 \\
\hline Criação de Animais & 759 & 282 & 1.041 & 74 & 3 & 77 & 1.118 & 1,9 \\
\hline Setor Secundário & 10.311 & 2.167 & 12.478 & 43.588 & 12.154 & 55.742 & 68.220 & 100,0 \\
\hline Construção & 699 & 256 & 955 & 34 & 3 & 37 & 992 & 1,5 \\
\hline Produção de Fios e Tecidos & 283 & 123 & 406 & 33.597 & 8.305 & 41.902 & 42.308 & 62,0 \\
\hline Produção de Peças de Vestuário & 3.643 & 553 & 4.196 & 8.880 & 1.014 & 9.894 & 14.090 & 20,7 \\
\hline Produção de Alimentos e Bebidas & 154 & 210 & 364 & 791 & 2.821 & 3.612 & 3.976 & 5,8 \\
\hline Madeira, Mobiliário e Similares & 2.690 & 465 & 3.155 & 31 & 0 & 31 & 3.186 & 4,7 \\
\hline Metalurgia & 1.823 & 509 & 2.332 & 14 & 4 & 18 & 2.350 & 3,4 \\
\hline Couros, Peles e Similares & 435 & 24 & 459 & 1 & 1 & 2 & 461 & 0,6 \\
\hline Outras Atividades de Transformação & 584 & 27 & 611 & 240 & 6 & 246 & 857 & 1,3 \\
\hline Setor Terciári 0 & 6.957 & 1.061 & 8.018 & 1.653 & 469 & 2.122 & 10.140 & 100,0 \\
\hline Comércio e Serviços Auxiliares & 3.875 & 11 & 3.886 & 419 & 3 & 422 & 4.308 & 42,6 \\
\hline Transportes & 1.838 & 721 & 2.559 & 10 & 0 & 10 & 2.569 & 25,3 \\
\hline Prestação de Serviços Gerais & 114 & 315 & 429 & 1.070 & 420 & 1.490 & 1.919 & 18,9 \\
\hline Prestação de Serviços Profissionais & 695 & 14 & 709 & 152 & 46 & 198 & 907 & 8,9 \\
\hline Administração, Defesa e Segurança Públicas & 435 & 0 & 435 & 2 & 0 & 2 & 437 & 4,3 \\
\hline Resíduo Ocupacional ${ }^{1}$ & 9.759 & 999 & 10.758 & 1.280 & 276 & 1.556 & 12.314 & 8,2 \\
\hline Total Ocupado & 61.824 & 23.192 & 85.016 & 50.176 & 14.102 & 64.278 & 149.294 & 100,0 \\
\hline População Residual ${ }^{2}$ & 63.188 & 57.048 & 120.236 & 80.196 & 36.112 & 116.308 & 236.544 & \\
\hline População Total & 125.012 & 80.240 & 205.252 & 130.372 & 50.214 & 180.586 & 385.838 & \\
\hline
\end{tabular}

Fonte: Listas Nominativas da População de 1831-32. Banco de Dados: Cedeplar/UFMG. Obs. 1: Outras Ocupações e Ocupações Mal Definidas ou Não Especificadas.

Obs. 2: Pessoas que não declararam informação - "sem informação" — ou que estão fora das fileiras de trabalho - inválidos, mendicantes, estudantes, rentistas, proprietários, capitalistas, etc.

Obs. 3: Participação (\%) de cada Ramo de Atividade no Setor Econômico a que pertence. O Resíduo Ocupacional refere-se à sua participação (\%) em relação ao Total Ocupado.

\section{Tabela 2 - Participação da População Ocupada por Ramo de Atividade e Setor Econômico - Segundo o Sexo e a Condição Social - Minas Gerais - 1831-32}

\begin{tabular}{lccccccc}
\hline \multirow{2}{*}{\multicolumn{1}{c}{ Setor Econômico/Ramo de Atividade }} & \multicolumn{2}{c}{ Homens } & \multicolumn{3}{c}{ Mulheres } \\
\cline { 2 - 6 } & Livre & Escravo & Total & Livre & Escravo & Total & Total \\
\cline { 2 - 6 } & 59,3 & 32,4 & 91,7 & 6,2 & 2,1 & 8,3 & 100,0 \\
Setor Primário & 59,6 & 32,1 & 91,7 & 6,3 & 2,0 & 8,3 & 100,0 \\
Agricultura & 55,3 & 36,4 & 91,7 & 5,2 & 3,1 & 8,3 & 100,0 \\
Atividades Extrativas & 67,9 & 25,2 & 93,1 & 6,6 & 0,3 & 6,9 & 100,0 \\
Criação de Animais & 15,1 & 3,2 & 18,3 & 63,9 & 17,8 & 81,7 & 100,0 \\
Setor Secundário & 70,5 & 25,8 & 96,3 & 3,4 & 0,3 & 3,7 & 100,0 \\
Construção & 0,7 & 0,3 & 1,0 & 79,4 & 19,6 & 99,0 & 100,0 \\
Produção de Fios e Tecidos & 25,9 & 3,9 & 29,8 & 63,0 & 7,2 & 70,2 & 100,0 \\
Produção de Peças de Vestuário & 3,9 & 5,3 & 9,2 & 19,8 & 71,0 & 90,8 & 100,0 \\
Produção de Alimentos e Bebidas & 84,4 & 14,6 & 99,0 & 1,0 & 0,0 & 1,0 & 100,0 \\
Madeira, Mobiliário e Similares & 77,6 & 21,6 & 99,2 & 0,6 & 0,2 & 0,8 & 100,0 \\
Metalurgia & 94,4 & 5,2 & 99,6 & 0,2 & 0,2 & 0,4 & 100,0 \\
Couros, Peles e Similares & 68,1 & 3,2 & 71,3 & 28,0 & 0,7 & 28,7 & 100,0 \\
Outras Atividades de Transformação & 68,6 & 10,5 & 79,1 & 16,3 & 4,6 & 20,9 & 100,0 \\
Setor Terciário & 89,9 & 0,3 & 90,2 & 9,7 & 0,1 & 9,8 & 100,0 \\
Comércio e Serviços Auxiliares & 71,5 & 28,1 & 99,6 & 0,4 & 0,0 & 0,4 & 100,0
\end{tabular}




\begin{tabular}{|c|c|c|c|c|c|c|c|}
\hline Prestação de Serviços Gerais & 5,9 & 16,4 & 22,3 & 55,8 & 21,9 & 77,4 & 100,0 \\
\hline Prestação de Serviços Profissionais & 76,6 & 1,6 & 78,2 & 16,8 & 5,0 & 21,8 & 100,0 \\
\hline Administração, Defesa e Segurança Públicas & 99,5 & 0,0 & 99,5 & 0,5 & 0,0 & 0,5 & 100,0 \\
\hline Resíduo Ocupacional ${ }^{1}$ & 79,2 & 8,2 & 87,4 & 10,4 & 2,2 & 12,6 & 100,0 \\
\hline Total Ocupado & 41,4 & 15,5 & 56,9 & 33,6 & 9,4 & 43,0 & 100,0 \\
\hline População Residual ${ }^{2}$ & 26,7 & 24,1 & 50,8 & 33,9 & 15,3 & 49,2 & 100,0 \\
\hline População Total & 32,4 & 20,8 & 53,2 & 33,8 & 13,0 & 46,8 & 100,0 \\
\hline
\end{tabular}

Fonte: Listas Nominativas da População de 1831-32. Banco de Dados: Cedeplar/UFMG. Obs. 1: Outras Ocupações e Ocupações Mal Definidas ou Não Especificadas.

Obs. 2: Pessoas que não declararam informação - "sem informação" — ou que estão fora das fileiras de trabalho — inválidos, mendicantes, estudantes, rentistas, proprietários, capitalistas, etc.

A Tabela 3 expõe a importância (em termos percentuais) de cada ramo de atividade na ocupação total, pondo em evidência as atividades que absorvem o maior e/ou menor contingente populacional ocupado. Ao lado das informações das duas tabelas anteriores, os dados da Tabela 3 permitem detectar o perfil econômico da Província em termos de sua população ocupada.

\section{Tabela 3 - Distribuição Percentual da População Ocupada por Ramo de Atividade - Segundo o Sexo e a Condição Social - Minas Gerais - 1831-32}

\begin{tabular}{lccccc}
\hline \multirow{2}{*}{ Ramo de Atividade } & \multicolumn{2}{c}{ Homens } & \multicolumn{2}{c}{ Mulheres } & Total \\
\cline { 2 - 5 } & Livre & Escravo & Livre & Escravo \\
\hline Agricultura & 50,01 & 71,71 & 6,55 & 7,30 & 34,74 \\
Atividades Extrativas & 5,05 & 8,85 & 0,58 & 1,21 & 3,78 \\
Criação de Animais & 1,23 & 1,22 & 0,15 & 0,02 & 0,75 \\
Construção & 1,13 & 1,10 & 0,07 & 0,02 & 0,66 \\
Produção de Fios e Tecidos & 0,46 & 0,53 & 66,96 & 58,89 & 28,34 \\
Produção de Peças de Vestuário & 5,89 & 2,38 & 17,70 & 7,19 & 9,44 \\
Produção de Alimentos e Bebidas & 0,25 & 0,91 & 1,58 & 20,00 & 2,66 \\
Madeira, Mobiliário e Similares & 4,35 & 2,01 & 0,06 & 0,00 & 2,13 \\
Metalurgia & 2,95 & 2,19 & 0,03 & 0,03 & 1,57 \\
Couros, Peles e Similares & 0,70 & 0,10 & 0,00 & 0,01 & 0,31 \\
Outras Atividades de Transformação & 0,94 & 0,12 & 0,48 & 0,04 & 0,57 \\
Comércio e Serviços Auxiliares & 6,27 & 0,05 & 0,84 & 0,02 & 2,89 \\
Transportes & 2,97 & 3,11 & 0,02 & 0,00 & 1,72 \\
Prestação de Serviços Gerais & 0,18 & 1,36 & 2,13 & 2,98 & 1,29 \\
Prestação de Serviços Profissionais & 1,12 & 0,06 & 0,30 & 0,33 & 0,61 \\
Administração, Defesa e Segurança Públicas & 0,70 & 0,00 & 0,00 & 0,00 & 0,29 \\
Resíduo Ocupacional ${ }^{1}$ & 15,79 & 4,31 & 2,55 & 1,96 & 8,25 \\
Total Ocupado & 100,0 & 100,0 & 100,0 & 100,0 & 100,0 \\
\hline
\end{tabular}

Fonte: Listas Nominativas da População de 1831-32. Banco de Dados: Cedeplar/UFMG. Obs. 1: Outras Ocupações e Ocupações Mal Definidas ou Não Especificadas.

Do exame dessas 3 tabelas depreende-se, de início, o papel fundamental dos setores Primário e Secundário na absorção de força de tra- 
balho. ${ }^{15}$ A ampla maioria encontra-se nesses dois setores - 85\% do total ocupado - embora sejam a Agricultura e a Produção de Fios e Tecidos (ou Indústria Têxtil) as atividades responsáveis, em conjunto, por $63 \%$ da ocupação total.

Isoladamente, pode-se perceber a importância relativa de cada um desses ramos de atividade: a Agricultura representa 88\% do Setor Primário e a Produção de Fios e Tecidos 62\% do Secundário. As Atividades Extrativas e a Criação de Animais são menores em termos de pessoas ocupadas (Tab. 1).

O Setor Secundário apresenta os resultados mais surpreendentes a esse respeito: são as atividades femininas - a Produção de Fios e Tecidos e a Produção de Peças do Vestuário - as responsáveis, em conjunto, por $83 \%$ das ocupações naquele setor. O Secundário, por sinal, no agregado, supera em 16\% o Setor Primário (Tab. 1).

Conforme se observa na Tabela 2, a também chamada Indústria Têxtil é um domínio quase exclusivo das mulheres. Estas contribuem com 82\% de seu trabalho para o Setor Secundário e 99\% para a Produção de Fios e Tecidos, especificamente. Outros redutos femininos são a Produção de Peças de Vestuário e a Produção de Alimentos e Bebidas, ambos concentrando $70 \%$ e $91 \%$ de mulheres em suas atividades produtivas respectivamente.

Pelos dados da Tabela 3 pode-se referendar, de outra forma, os resultados acima. A Agricultura e a Produção de Fios e Tecidos constituem as atividades mais importantes da economia em termos de pessoas ocupadas. A maioria dos homens encontra-se no trabalho agrícola - 50\% dos livres e $72 \%$ dos escravos. O uso do trabalho escravo na Agricultura, em tal proporção, dá substância ao argumento desenvolvido inicialmente, segundo o qual o cultivo da terra apresentara-se como uma alternativa factível quando do declínio da mineração.

Paralelamente, é a Produção de Fios e Tecidos que ocupa a ampla maioria das mulheres, tanto livres quanto escravas - 67\% e 59\% respectivamente. Este resultado confirma, igualmente, a suposição atrás estabelecida de que a Indústria Têxtil encontrava-se entre aquelas alternativas econômicas. A força de trabalho escrava havia de ser usada produtivamente de forma a gerar produtos comercializáveis - mercadorias - e lucros para seus proprietários, consequentemente. Pelas evidências sobressai uma nítida especialização ocupacional: aos homens (livres e escravos) o cultivo da terra, às mulheres (livres e escravas) fios e tecidos.

A Tabela 4, apresentada a seguir, expõe a participação das mulheres em ocupações selecionadas nas quais elas são predominantes. Chama-se a atenção para as ocupações do Setor Secundário que reúne as

15 As tabulações que deram origem aos resultados aqui exibidos encontram-se na pesquisa da autora supra citada (2004). Estes originais encontram-se disponíveis na Biblioteca da FAPEMIG 
informações mais relevantes. A Indústria Têxtil é movida majoritariamente por mulheres "fiandeiras" e "tecedeiras", as produtoras por excelência de fios e tecidos. Na Produção de Peças do Vestuário sobressaem as "costureiras", e o processamento de alimentos em geral recai sobre as "cozinheiras", as quais transformavam grãos e outros produtos da terra em produtos próprios para o consumo.

\section{Tabela 4 - Categorias Ocupacionais em que as Mulheres são Predominantes por Setor Econômico e Ramo de Atividade Minas Gerais - 1831-32}

\begin{tabular}{cccc}
\hline \multirow{2}{*}{ Setor/Ramo/Ocupação } & \multicolumn{2}{c}{ Mulheres } & Total \\
\cline { 2 - 3 } & Livre & Escrava & \\
\cline { 2 - 3 } Setor Secundário & 63,9 & 17,8 & 81,7 \\
Produção de Fios e Tecidos & 79,4 & 19,6 & 99,0 \\
Fiandeiras & 79,5 & 19,7 & 99,2 \\
Tecedeira & 80,1 & 18,3 & 98,4 \\
Fiandeira e Tecedeira & 66,7 & 25,2 & 91,9 \\
Produção de Peças do Vestuário & 63,0 & 7,2 & 70,2 \\
Costureira & 89,6 & 10,0 & 99,6 \\
Produção de Alimentos e Bebidas & 19,8 & 71,0 & 90,8 \\
Cozinheiras & 16,4 & 78,1 & 94,5 \\
Setor Terciário & 16,3 & 4,6 & 20,9 \\
Prestação de Serviços Gerais & 55,8 & 21,9 & 77,7 \\
Lavadeira & 57,5 & 41,1 & 98,6 \\
A Serviço da Casa & 80,1 & 8,3 & 88,4 \\
Meretriz & 100,0 & 0,0 & 100,0 \\
Engomadeira & 32,1 & 64,3 & 96,4 \\
Mucamba & 0,0 & 100,0 & 100,0 \\
Rezadeira & 100,0 & 0,0 & 100,0 \\
Prestação de Serviços Profissionais & 16,8 & 5,1 & 21,9 \\
Florista & 100,0 & 0,0 & 100,0 \\
Enfermeira & 44,4 & 33,3 & 77,7 \\
Parteira & 100,0 & 0,0 & 100,0 \\
Recolhidas no Convento & 43,4 & 43,4 & 86,8 \\
\hline Fonn
\end{tabular}

Fonte: Listas Nominativas da População de 1831-32. Banco de Dados: Cedeplar/UFMG.

O Setor Terciário, embora em seu conjunto não represente um domínio feminino, reúne segmentos da força de trabalho liderados amplamente por mulheres. Não podendo ser considerados em detalhe no presente contexto, fazem-se notar, particularmente, por constituírem a base sobre a qual o trabalho das mulheres, pobres e negras em especial, viria a se desenvolver ao longo dos séculos XIX e XX. A chamada "empregada doméstica" da era pós-escravidão tem suas raízes nas ocupações que lhes foram atribuídas desde os tempos coloniais. Na Prestação de Serviços Profissionais, encontram-se já as "parteiras" e "enfermeiras", ocupações desempenhadas por mulheres que reaparecem em seus descendentes e permanecem latentes nas gerações atuais. 
Completando esse conjunto de tabelas, a Indústria Têxtil vem a ser apresentada (Tabela 5) de acordo com as sucessivas etapas da produção, ou seja, desde a preparação das fibras têxteis, passando pela fiação, pela tecelagem até o acabamento do tecido. A Fiação e a Tecelagem constituem os principais processos desse ramo de atividade, sem os quais este não existiria. ${ }^{16}$

\section{Tabela 5 - Composição da População Ocupada na Produção de Fios e Tecidos Segundo o Sexo e a Condição Social Minas Gerais - 1831-32}

\begin{tabular}{|c|c|c|c|c|c|c|c|}
\hline \multirow{2}{*}{ Ocupação } & \multicolumn{3}{|c|}{ Homens } & \multicolumn{3}{|c|}{ Mulheres } & \multirow{2}{*}{ Total } \\
\hline & Livre & Escravo & Total & Livre & Escravo & Total & \\
\hline Trabalha com algodão e lã & - & - & - & 76 & 4 & 80 & 80 \\
\hline Algodão & - & - & - & 75 & 4 & 79 & 79 \\
\hline Fábrica de lã e algodão & - & - & - & 1 & - & 1 & 1 \\
\hline Descaroça mento e/ou Preparação & - & - & - & 7 & 2 & 9 & 10 \\
\hline Descaroça algodão & - & 1 & 1 & 4 & 1 & 5 & 6 \\
\hline Descaroça & - & - & - & 3 & - & 3 & 3 \\
\hline Abre lã & - & - & - & - & 1 & 1 & 1 \\
\hline Cardação & 1 & 7 & 8 & - & - & - & 8 \\
\hline Cardador & 1 & 7 & 8 & - & - & - & 8 \\
\hline Cardação e Fiação & - & - & - & 1 & - & 1 & 1 \\
\hline Fia e carda lã & - & - & - & 1 & - & 1 & 1 \\
\hline Fiação & 225 & 89 & 314 & 31.262 & 7.746 & 39.008 & 39.322 \\
\hline $\mathrm{Fia}^{3}$ & 222 & 87 & 309 & 30.562 & 7.645 & 38.207 & 38.516 \\
\hline Fia linho & - & 2 & 2 & 36 & 2 & 38 & 40 \\
\hline A fiar algodão & 2 & - & 2 & 657 & 94 & 751 & 753 \\
\hline Fia lam e algudão & - & - & - & 1 & - & 1 & 1 \\
\hline Fiadeira em companhias dos pais & - & - & - & 1 & - & 1 & 1 \\
\hline Aprende a fiar & - & - & - & 2 & 5 & 7 & 7 \\
\hline Fia e muda & - & - & - & 2 & - & 2 & 2 \\
\hline Fiar e esmolas & 1 & - & 1 & 1 & - & 1 & 2 \\
\hline Fiação e Tecelagem & 22 & 13 & 35 & 289 & 109 & 398 & 433 \\
\hline De fiar e tear panos & 22 & 13 & 35 & 242 & 67 & 309 & 344 \\
\hline Fião algodão e tecem & - & - & - & 25 & 29 & 54 & 54 \\
\hline Fião e tecem algodão e lan & - & - & - & 20 & 12 & 32 & 32 \\
\hline Fiadeira e teceloa & - & - & - & 2 & 1 & 3 & 3 \\
\hline Tecelag em & 27 & 13 & 40 & 1.948 & 444 & 2.392 & 2.432 \\
\hline Tece & 6 & 1 & 7 & 1.745 & 402 & 2.147 & 2.154 \\
\hline Tece algodão & 1 & - & 1 & 40 & 3 & 43 & 44 \\
\hline Teceloa, tecelã, tecelona, tecelão & 20 & 12 & 32 & 163 & 39 & 202 & 234 \\
\hline Tecelagem e Tintureira & - & - & - & 1 & - & 1 & 1 \\
\hline Tecedeira e tintureira & - & - & - & 1 & - & 1 & 1 \\
\hline Tintureira & - & - & - & 10 & - & 10 & 10 \\
\hline Tintureira, tingideira & - & - & - & 7 & - & 7 & 7 \\
\hline Tingideira & - & - & - & 3 & - & 3 & 3 \\
\hline Cordoeiro & 1 & - & 1 & - & - & - & 1 \\
\hline Serigueiro & 7 & - & 7 & 3 & - & 3 & 10 \\
\hline Total & 283 & 123 & 406 & 33.597 & 8.305 & 41.902 & 42.308 \\
\hline
\end{tabular}

Fonte: Listas Nominativas da População de 1831-32. Banco de Dados: Cedeplar/UFMG.

16 Informações detalhadas de cada processo/etapa de produção encontram-se em MACEDO, Concessa Vaz de Diferenciação Ocupacional e Salarial do Operariado Feminino "vis-à-vis" O Masculino na Indústria Brasileira. 
Dada a base técnica então prevalecente, uma enorme quantidade de fios era necessária para tecer a mais estreita/simples peça de tecido/ pano. Não é de se espantar, portanto, que o número de "fiandeiras" sobrepujasse em muito o das "tecedeiras". Para os familiarizados com o tema, este é um aspecto crucial por detrás dos avanços tecnológicos que fizeram da Inglaterra a "Oficina do Mundo" no século XIX. Entre as várias "revoluções" que ocorreram naquele país a partir da segunda metade do século XVIII, a "revolução na indústria têxtil" talvez tenha sido, senão a mais importante, a que mereceu um sem número de escritos e publicações devido ao advento da "máquina de fiar". ${ }^{17} \mathrm{O}$ descompasso existente entre a fiação (realizada com fusos e/ou rodas de fiar) e a tecelagem (realizada em teares parcialmente mecanizados) explica a importância do trabalho das "fiandeiras", cujo produto (o fio) só poderia ser obtido expandindo o número de pessoas (mulheres, no caso) ocupadas nessa função ou, alternativamente, intensificando o tempo de trabalho de cada fiandeira. De uma forma ou de outra, fiava-se em qualquer canto e a qualquer hora, porque os teares não podiam esperar... Portanto, a diferença entre o número (grande e expressivo) de "fiandeiras" e o de "tecedeiras" (significativamente menor que o das "fiandeiras") resulta ser devida, em grande medida, a uma questão técnica. ${ }^{18}$ Como sucedeu na Inglaterra e depois em outros países uns após os outros, a introdução e difusão da "fiandeira automática" viriam alterar completamente essa desproporção técnica entre a fiação e a tecelagem. No Brasil, e em Minas Gerais, isso só debutaria em finais do século XIX e difundir-se-ia no XX.

Resumindo os traços mais importantes dos dados acima classificados, tem-se que:

1. metade da força de trabalho masculina livre encontrava-se na Agricultura, elevando-se para $72 \%$ a participação dos cativos;

2. mais de 2/3 das mulheres livres produziam Fios e Tecidos, dos mesmos se ocupando $60 \%$ das mulheres escravas;

3. as ocupações masculinas e femininas eram marcadamente estratificadas, fazendo da economia mineira de meados dos Oitocentos um caso exemplar de divisão sexual do trabalho social; e,

4. em conjunto, os dados de ocupação permitem afirmar que a "Indústria de Transformação" era, tal como refletido nas Listas de 1831-32, eminentemente feminina.

17 A "Jenny" (1770), a "Frame" (1769) e a "Spinning Mule" (1780). Vide MACEDO, Concessa Vaz de. As Mulheres, seus Ofícios e suas Técnicas.

18 Além disso, é possível conjeturar que, dada essa desproporção técnica e dada a acentuada concentração da indústria têxtil em um número reduzido de distritos (conforme estudo de Macedo, 2004), muitas áreas da Província viriam a se especializar na produção de fios (fiação) para atender a demanda dos distritos onde a indústria achava-se concentrada. 


\section{Estrutura ocupacional da população de Minas Gerais segundo o recenseamento de 1872}

No Censo de 1872 lê-se "profissão" ao invés de "ocupação". Merrick e Graham, no estudo "População e Desenvolvimento Econômico no Brasil" (1981), entenderam "profissão" como um conceito "antigo brasileiro", "precursor do que hoje seria considerado como ocupação". ${ }^{19}$ Em função de seus objetivos, qual seja, observar o crescimento da população ativa do Brasil de 1872 a 1970, estabeleceram uma classificação cujos ajustes empreendidos (seguindo as recomendações das Nações Unidas) terminaram por obscurecer, e mesmo ocultar, as informações sobre ocupações originalmente registradas.

Isso não constituiria um problema maior caso os resultados derivados de tal classificação não tivessem servido de fonte para outros estudos, consolidando e perpetuando uma versão particular e questionável.

Como foi mencionado na Introdução, as "Estatísticas Históricas do Brasil" do IBGE, reeditadas em 1990, adotaram a classificação de Merrick e Graham, divulgando-a amplamente. ${ }^{20}$ Se utilizada para Minas Gerais, dela se depreende um perfil ocupacional da economia mineira muito distinto daquele que se obteria se todas as ocupações censitárias tivessem sido reputadas enquanto tais.

O esquema proposto pelos autores citados (para o Brasil, mas aplicável a todas as províncias, dado o caráter geral do Censo) reduz a economia mineira praticamente a dois setores de atividade: a Agricultura e os Serviços. O primeiro prepondera em termos ocupacionais, e os Serviços equivalem, em quase sua totalidade, ao Serviço Doméstico. A Indústria é inexpressiva, referindo-se tão somente às atividades de Construção e de Mineração. O restante das pessoas ocupadas está incluído numa categoria criada para esse fim denominada "Indefinidos". Sob este rótulo encontra-se a "indústria de roupas", a qual, segundo a publicação do IBGE, "inclui costureiros e empregados em vestuário e toucador" (op. cit.). Em resumo, não há Indústria de Transformação na economia mineira, exceto a indústria de construção, assumindo-se a mineração como uma atividade extrativa. Não há, pois, Indústria Têxtil, tendo sido as atividades femininas consideradas explicitamente como "ocupações duvidosas", definidas de maneira imprecisa", não podendo, portanto, serem incluídas em um "grupo ativo". ${ }^{21}$

As Listas de 1831-32 foram elaboradas contendo informações individualizadas do nome, idade, condição (livre ou escravo), estado conju-

19 MERRICK, Thomas W. GRAHAM, Douglas H. População e Desenvolvimento Econômico no Brasil. Rio de Janeiro: Zahar, 1981, p. 188-189.

20 Estatísticas Históricas do Brasil. Séries Econômicas, Demográficas e Sociais - 1550 a 1988. Rio de Janeiro: IBGE, 1990 (2a ed. revista e atualizada do vol. 3 de Séries Estatísticas Retrospectivas), p.70, Tab.3.1.

21 MERRICK, Thomas W. GRAHAM, Douglas H. População e Desenvolvimento Econômico no Brasil, p.191. 
gal e ocupação. Como visto, foram declaradas 787 ocupações ${ }^{22}$ cujas denominações, claras e precisas em sua maioria, permitem saber quantos homens e mulheres dependiam de uma atividade particular para sua sobrevivência. O Recensemanento de 1872 arrola 37 categorias, das quais, subtraídos os "capitalistas e proprietários"23 e os "sem profissão", restam 35 categorias associadas diretamente ao exercício de uma atividade específica, constituindo, com propriedade, categorias ocupacionais.

A classificação que ora se apresenta teve como fonte os quadros (digitalizados e corrigidos quanto à consistência interna das informações) divulgados pelo Centro Brasileiro de Análise e Planejamento - CEBRAP — em 2004. ${ }^{24}$ Os dados originais, assim revistos, foram agrupados em conformidade com o esquema pré-estabelecido utilizado para 1831-32.

Como antes, toda a população foi classificada como Ocupada e NãoOcupada, esta última representando 36\% do total arrolado. A população total de Minas Gerais classificada "em relação à profissão" monta a 2.037.665 habitantes, o que significa um montante da ordem de 0,1\% inferior ao "total de almas" registrado no Censo (2.039.735). As tabelas que se seguem respeitam as orientações estabelecidas e serão assim descritas (Tabelas 6 a 9).

Em 1873, ano em que foi realizado o recenseamento em Minas Gerais, $58 \%$ das pessoas ocupadas encontravam-se nos setores Primário e Secundário (Tab. 6). A Agricultura seguia sendo a atividade que mais absorvia trabalhadores, seguida da Produção de Peças do Vestuário e da Indústria Têxtil, agora em ordem invertida em termos de importância.

\section{Tabela 6 - Composição da População Ocupada por Ramo de Atividade e Setor Econômico Segundo o Sexo e a Condição Social Minas Gerais - 1873}

\begin{tabular}{lcccccccc}
\hline \multirow{2}{*}{$\begin{array}{l}\text { Setor Econômico/ } \\
\text { Ramo de Atividade }\end{array}$} & \multicolumn{3}{c}{ Homens } & \multicolumn{3}{c}{ Mulheres } & \multirow{2}{*}{ Total } & $\%^{3}$ \\
\cline { 2 - 7 } & Livre & Escravo & Total & Livre & Escravo & Total & \\
\hline Setor Primário & 274.231 & 79.886 & 354.117 & 104.588 & 36.334 & 140.922 & 495.039 & 100,0 \\
Agricultura & 266.090 & 78.257 & 344.347 & 104.481 & 36.258 & 140.739 & 485.086 & 98,0 \\
Atividades Extrativas & 6.064 & 1.625 & 7.689 & 10 & 0 & 10 & 7.699 & 1,6 \\
Criação de Animais & 2.077 & 4 & 2.081 & 97 & 76 & 173 & 2.254 & 0,6 \\
Setor Secundário & 33.399 & 3.507 & 36.906 & 201.554 & 22.723 & 224.277 & 261.183 & 100,0 \\
Construção & 2.623 & 327 & 2.950 & 5 & 0 & 5 & 2.955 & 1,1 \\
Têxtil & 5.894 & 951 & 6.845 & 58.116 & 5.505 & 63.621 & 70.466 & 27,0 \\
Vestuário & 7.926 & 645 & 8.571 & 141.914 & 17.159 & 159.073 & 167.644 & 64,2
\end{tabular}

22 Este é o número de ocupações constante do Banco de Dados do Cedeplar.

23 A categoria "capitalistas e proprietários" indica uma circunstância, um estado, e não uma ação, esta entendida como um conjunto de atos que convergem todos para um fim determinado, caracterizando, conforme já definido, uma ocupação, no sentido próprio e adotada neste estudo como categoria básica. Os dados digitalizados constam do Banco de Dados do Cedeplar.

24 "Os Recenseamentos Gerais do Brasil no Século XIX: 1872 e 1890". São Paulo: CEBRAP, 2004, apoio FAPESP. 


\begin{tabular}{lcccccccc} 
Madeira & 9.739 & 969 & 10.708 & 0 & 22 & 22 & 10.730 & 4,1 \\
Metalurgia & 5.753 & 545 & 6.298 & 1.519 & 37 & 1.556 & 7.854 & 3,0 \\
Couros e Pelos & 1.464 & 70 & 1.534 & 0 & 0 & 0 & 1.534 & 0,6 \\
Setor Terciário & 21.773 & 47 & 21.820 & 1.083 & 5 & 1.088 & 22.908 & 100,0 \\
Comércio & 14.665 & 0 & 14.665 & 309 & 0 & 309 & 14.974 & 65,4 \\
Serv. Profissionais & 3.375 & 4 & 3.379 & 774 & 5 & 779 & 4.158 & 18,2 \\
Serv. Públicos & 3.733 & 43 & 3.776 & 0 & 0 & 0 & 3.776 & 16,4 \\
Resíduo Ocupacional $^{1}$ & 191.713 & 55.552 & 247.265 & 228.377 & 53.950 & 282.327 & 529.592 & 40,5 \\
Total Ocupado $^{\text {População Residual }}{ }^{2}$ & 521.116 & 138.992 & 660.108 & 535.602 & 113.012 & 648.614 & 1.308 .722 & 100,0 \\
População Total $^{326.403}$ & 60.400 & 386.803 & 284.042 & 58.098 & 342.140 & 728.943 & \\
\hline
\end{tabular}

Fonte: CEBRAP/FAPESP, "Os Recenseamentos Gerais do Brasil no Século XIX: 1872 e 1890", 2004.

Obs. 1: Outras Ocupações e Ocupação Mal Definidas ou Não Especificadas ("Serviço Doméstico", "Criados e Jornaleiros" e "Manufatureiros e Fabricantes")

Obs. 2: "Proprietários e Capitalistas" e "Sem Profissão"

Obs. 3: Participação (\%) de cada Ramo de Atividade no Setor Econômico a que pertence.

O Resíduo Ocupacional refere-se à sua participação (\%) em relação ao Total Ocupado.

Os ramos do Vestuário e dos Tecidos, predominantemente femininos, respondem por $91 \%$ do total ocupado na Indústria de Transformação (o Setor Secundário), mantendo a tendência já observada em 1831-32.

Tabela 7 - Participação da População Ocupada por Ramo de Atividade e Setor Econômico Segundo o Sexo e a Condição Social Minas Gerais - 1873

\begin{tabular}{|c|c|c|c|c|c|c|c|}
\hline \multirow{2}{*}{$\begin{array}{l}\text { Setor Econômico/ } \\
\text { Ramo de Atividade }\end{array}$} & \multicolumn{3}{|c|}{ Homens } & \multicolumn{3}{|c|}{ Mulheres } & \multirow{2}{*}{ Total } \\
\hline & Livre & Escravo & Total & Livre & Escravo & Total & \\
\hline Setor Primário & 55,4 & 16,1 & 71,5 & 21,1 & 7,3 & 28,5 & 100,0 \\
\hline Agricultura & 54,9 & 16,1 & 71,0 & 21,5 & 7,5 & 29,0 & 100,0 \\
\hline Atividades Extrativas & 78,8 & 21,1 & 99,9 & 0,1 & 0,0 & 0,1 & 100,0 \\
\hline Criação de Animais & 92,1 & 0,2 & 92,3 & 4,3 & 3,4 & 7,7 & 100,0 \\
\hline Setor Secundário & 12,8 & 1,3 & 14,1 & 77,2 & 8,7 & 85,9 & 100,0 \\
\hline Construção & 88,8 & 11,1 & 99,8 & 0,2 & 0,0 & 0,2 & 100,0 \\
\hline Indústria Têxtil & 8,4 & 1,3 & 9,7 & 82,5 & 7,8 & 90,3 & 100,0 \\
\hline Prod. de Peças do Vestuário & 4,7 & 0,4 & 5,1 & 84,7 & 10,2 & 94,9 & 100,0 \\
\hline Madeira & 90,8 & 9,0 & 99,8 & 0,0 & 0,2 & 0,2 & 100,0 \\
\hline Metalurgia & 73,2 & 6,9 & 80,1 & 19,3 & 0,5 & 19,8 & 100,0 \\
\hline Couros e Pelos & 95,4 & 4,6 & 100,0 & 0,0 & 0,0 & 0,0 & 100,0 \\
\hline Setor Terciário & 95,0 & 0,2 & 95,2 & 4,8 & 0,0 & 4,8 & 100,0 \\
\hline Comércio & 97,9 & 0,0 & 97,9 & 2,1 & 0,0 & 2,1 & 100,0 \\
\hline Serviços Profissionais & 81,2 & 0,1 & 81,3 & 18,6 & 0,1 & 18,7 & 100,0 \\
\hline Serviços Públicos & 98,9 & 1,1 & 100,0 & 0,0 & 0,0 & 0,0 & 100,0 \\
\hline Resíduo Ocupacional & 36,2 & 10,5 & 46,7 & 43,1 & 10,2 & 53,3 & 100,0 \\
\hline Total Ocupado & 39,8 & 10,6 & 50,4 & 40,9 & 8,6 & 49,5 & 100,0 \\
\hline População Residual & 44,8 & 8,3 & 53,1 & 39,0 & 8,0 & 46,9 & 100,0 \\
\hline População Total & 41,6 & 9,8 & 51,4 & 40,2 & 8,4 & 48,6 & 100,0 \\
\hline
\end{tabular}

Fonte: CEBRAP/FAPESP, "Os Recenseamentos Gerais do Brasil no Século XIX: 1872 e 1890", 2004.

Obs. 1: Outras Ocupações e Ocupação Mal Definidas ou Não Especificadas ("Serviço Doméstico", "Criados e Jornaleiros" e "Manufatureiros e Fabricantes")

Obs. 2: "Proprietários e Capitalistas" e "Sem Profissão" 
A Indústria Têxtil (tab. 7) continua sendo um domínio das mulheres, quase exclusivamente, bem como a Produção de Peças do Vestuário, ambos os ramos comandando as ocupações do conjunto do Setor Secundário. No primeiro ramo as mulheres representam 90,3\% do total aí ocupado, enquanto 94,4\% são mulheres na Produção de Peças do Vestuário.

Os dados apresentados na Tabela 8 apontam para uma absorção menor da força de trabalho feminina na Indústria Têxtil em relação ao Total Ocupado se for lembrada sua presença marcante em 1831-32. Embora ainda expressiva em termos de sua participação no conjunto da Indústria de Transformação, a redução verificada sugere reflexões no âmbito do próprio censo, visto que, a essa altura do período histórico em consideração, a economia mineira ainda estava longe do predomínio das fábricas mecanizadas e de suas "fiandeiras automáticas" de modo a poder dispensar o trabalho das fiandeiras (de roda e, também, de fuso), bem como o das tecedeiras (de teares parcialmente mecanizadas, mas movidos a força humana).

\section{Tabela 8 - Distribuição Percentual da População Ocupada por Ramo de Atividade Segundo o Sexo e a Condição Social Minas Gerais - 1873}

\begin{tabular}{lccccc}
\hline \multirow{2}{*}{ Ramo de Atividade } & \multicolumn{2}{c}{ Homens } & \multicolumn{2}{c}{ Mulheres } & Total \\
\cline { 2 - 4 } & Livre & Escravo & Livre & Escravo & \\
\hline Agricultura & 51,06 & 56,30 & 19,51 & 32,08 & 37,07 \\
Atividades Extrativas & 1,16 & 1,17 & 0,00 & 0,00 & 0,59 \\
Criação de Animais & 0,40 & 0,00 & 0,02 & 0,07 & 0,17 \\
Construção & 0,50 & 0,24 & 0,00 & 0,00 & 0,23 \\
Indústria Têxtil & 1,13 & 0,68 & 10,85 & 4,87 & 5,38 \\
Prod. de Peças do Vestuário & 1,52 & 0,46 & 26,50 & 15,18 & 12,81 \\
Madeira & 1,87 & 0,70 & 0,00 & 0,02 & 0,82 \\
Metalurgia & 1,10 & 0,39 & 0,28 & 0,03 & 0,60 \\
Couros e Pelos & 0,28 & 0,05 & 0,00 & 0,00 & 0,12 \\
Comércio & 2,81 & 0,00 & 0,06 & 0,00 & 1,14 \\
Serviços Profissionais & 0,65 & 0,00 & 0,14 & 0,00 & 0,32 \\
Serviços Públicos & 0,72 & 0,03 & 0,00 & 0,00 & 0,29 \\
Resíduo Ocupacional: & & & & \\
Serviços Domésticos & 6,46 & 25,67 & 40,32 & 40,83 & 25,33 \\
Criados e Jornaleiros & 30,25 & 14,29 & 2,30 & 6,91 & 15,10 \\
Manufatureiros e Fabricantes & 0,08 & 0,00 & 0,02 & 0,00 & 0,04 \\
Total Ocupado & 100,0 & 100,0 & 100,0 & 100,0 & 100,0
\end{tabular}

Fonte: CEBRAP/FAPESP, "Os Recenseamentos Gerais do Brasil no Século XIX: 1872 e 1890", 2004.

A tabela 9 expõe a participação das mulheres em categorias ocupacionais selecionadas onde são maioria (nos moldes da tabela 4 anterior), sendo notória a semelhança entre as funções desempenhadas por elas em um e outro documento. 


\section{Tabela 9 - Categorias Ocupacionais em que as Mulheres são Predominantes por Setor Econômico e Ramo de Atividade Minas Gerais - 1873}

\begin{tabular}{|c|c|c|c|}
\hline \multirow{2}{*}{ Setor/Ramo/Ocupação } & \multicolumn{2}{|c|}{ Mulheres } & \multirow{2}{*}{ Total } \\
\hline & Livre & Escrava & \\
\hline Setor Secundário & 77,2 & 8,7 & 85,9 \\
\hline Indústria Têxtil & 82,5 & 7,8 & 90,3 \\
\hline em tecidos & 82,5 & 7,8 & 90,3 \\
\hline tinturaria & 55,6 & 0,0 & 55,6 \\
\hline Producão de Pecas do Vestuário & 84,7 & 10,2 & 94,9 \\
\hline costureiras & 89,2 & 10,8 & 100,0 \\
\hline de chapéus & 51,1 & 0,6 & 51,7 \\
\hline Setor Terciário & 4,8 & 0,0 & 4,8 \\
\hline Serviços Profissionais & 18,6 & 0,1 & 18,7 \\
\hline parteiras & 98,0 & 1,4 & 99,4 \\
\hline Resíduo Ocupacional & 43,1 & 10,2 & 53,3 \\
\hline Serviços Domésticos & 65,2 & 13,9 & 79,1 \\
\hline
\end{tabular}

Fonte: CEBRAP/FAPESP, "Os Recenseamentos Gerais do Brasil no Século XIX: 1872 e 1890", 2004.

Os dados assim classificados indicam que, em linhas gerais, as conclusões extraídas das Listas Nominativas permanecem válidas, em sua quase totalidade, para 1873.

Com efeito, mais da metade da força de trabalho masculina (livre e escrava) encontrava-se na Agricultura, base da economia mineira Oitocentista, as ocupações masculinas e femininas mantinham-se firmemente demarcadas, e a Indústria de Transformação (ou Setor Secundário) não deixara de ser eminentemente feminina, ou seja, dominada pelas mulheres. Todavia, volta-se a salientar o descenso do número absoluto e relativo das mulheres na atividade têxtil.

Como chamou a atenção de vários autores, inclusive de Merrick e Graham, ${ }^{25}$ o Recenseamento de 1872 registra um número considerável de pessoas ocupadas em "Serviço Doméstico" e "Criados e Jornaleiros", estas, sem dúvida, categorias ocupacionais indefinidas, mal definidas e "duvidosas", segundo a definição de ocupação aqui adotada. É oportuno, a esse respeito, resgatar-se a sugestão reparadora de Martins, feita ao final de seu estudo sobre "A Indústria Têxtil Doméstica de Minas Gerais no século XIX", a saber:

"[...] o número de pessoas empregadas na produção artesanal era certamente muito maior que aquele indicado pelo censo, porque muitas mulheres

25 MERRICK, Thomas W. GRAHAM, Douglas H. População e Desenvolvimento Econômico no Brasil. 
que fiavam e teciam como parte de sua rotina doméstica devem ter sido classificadas como "serviço doméstico" ou "sem profissão" (1983, p. 88-89). ${ }^{26}$

A atividade de fiação à época, com seus instrumentos disponíveis, era um trabalho sem fim, compelindo as mulheres a fazê-lo a qualquer hora e em qualquer lugar para suprir os teares. É bastante provável que um número significativo de fiandeiras tenha sido subtraído da profissão designada, no Censo, "operários em tecido", ficando esta restringida (literalmente) à tecelagem propriamente dita (ou produção de tecidos).

A importância da Indústria Têxtil não fica diminuída, contudo. No Brasil, em 1872, segundo o mesmo recenseamento, havia 139.488 trabalhadores nessa indústria, dos quais 50,5\% encontravam-se em Minas Gerais. Mais de $90 \%$ da força de trabalho era composta de mulheres, tanto em Minas quanto no país como um todo. Sob essas condições, não se pode deixar de admitir que as mulheres trabalhadoras mineiras representavam o país na qualidade de produtoras de tecidos, ou melhor, de artesãs de fios e tecidos.

\section{Observações finais}

Este estudo não pretendeu senão contribuir para o entendimento da natureza da economia mineira do século XIX, a partir dos dados gerais para a Província constantes dos censos disponíveis. Reavaliados sob novos critérios, os resultados obtidos vêm validar e consolidar o que já fora indicado por Libby, no que se refere ao lugar de destaque da indústria têxtil no setor de transformação. Vêm, ademais, recobrar seu espaço relegado pelas Estatísticas Históricas do IBGE, restituindo-Ihe o lugar que the fora atribuído pelos recenseadores do século XIX, em 1872.

Muito ainda há que ser respondido a seu respeito, em particular quanto à sua organização. As informações sobre as ocupações do comércio e do transporte, especialmente as das Listas de 1831-32, claramente iluminam o caminho a ser perseguido, mas não fornecem todos os elementos necessários. Quem eram os negociantes de fios e tecidos, como e sob quais condições esses produtos eram elaborados e quem eram os beneficiários dos ganhos derivados dessa atividade mercantil são algumas questões, dentre outras, a serem investigadas.

A propósito, a divisão da indústria têxtil entre o setor camponês (posseiros e pequenos sitiantes) e a grande propriedade rural (utilizadora de

26 MARTINS, Roberto Borges. A Indústria Têxtil Doméstica de Minas Gerais no Século XIX. ANAIS: I Seminário sobre a Economia Mineira. Diamantina. Cedeplar/FACE/UFMG, 198, p. 88-89. Segundo Libby, o declínio da indústria têxtil observado em 1872 devia-se, fundamentalmente, à concorrência dos tecidos ingleses, que deslocavam do comércio o "pano de Minas", LIBBY, Douglas Cole. Transformação e Trabalho em uma Economia Escravista. 
trabalho escravo), proclamada por Martins e refutada por Libby - em nome de sua difusão e de sua dispersão por todas as camadas sociais —, ${ }^{27}$ prossegue sendo uma disputa polêmica, cuja solução depende de novas investigações. ${ }^{28}$

Espera-se que outras pesquisas venham preencher lacunas como essas mencionadas, contribuindo para uma compreensão mais acurada do legado econômico de gerações passadas, sobretudo das mulheres produtoras de riqueza material na forma de fios e tecidos.

\section{REFERÊNCIAS BIBLIOGRÁFICAS}

ARMSTRONG, W. A. The Use of Information about Occupation. In: WRIGLEY, E. A. (ed.). Nineteenth-Century Society Essay in the Use of Quantitative Methods for the Study of Social Data. Cambridge at the University Press, 1972. (A Publication of the Cambridge Group for the History of Population and Social Structure).

BERGAD, Laird, W. Escravidão e História Econômica - Demografia de Minas Gerais, 1720-1888. São Paulo: EDUSC, 2004.

CHAVES, Cláudia Maria das Graças. Melhoramentos no Brasil: Integração e Mercado na América Portuguesa (1780-1822). Tese de doutoramento, Universidade Federal Fluminense, Departamento de História. Niterói, 2001.

FRANCO, Maria Sylvia de C. Homens Livres na Terra Escravocrata. São Paulo: UNESP, 1977.

FURTADO, Celso. Formação Econômica do Brasil. São Paulo: Nacional, 1976.

KOWARICK, Lúcio. Trabalho e Vadiagem - A Origem do Trabalho Livre no Brasil. São Paulo: Brasiliense, 1987.

GAMA, Ruy. A Tecnologia e o Trabalho na História: São Paulo: Nobel/EDUSP, 1987.

GIROLETTI, Domingos. Fábrica, Convento, Disciplina. Belo Horizonte: Imprensa Oficial, 1991.

LIBBY, Douglas Cole. Transformação e Trabalho em uma Economia Escravista - Minas Gerais no Século XIX. São Paulo: Brasiliense, 1988.

MACEDO, Concessa Vaz de. As Mulheres, seus Ofícios e suas Técnicas: Processo de Trabalho nas Indústrias Têxteis Britânicas antes da Revolução Industrial. Tese de doutoramento, Universidade de São Paulo, Departamento de História. São Paulo, 1996.

MACEDO, Concessa Vaz de. Trabalho Feminino e suas Técnicas: Processo de Trabalho e Organização da Indústria de Fios e Tecidos em Minas Gerais no Século XIX. Relatório Final de Pesquisa: Cedeplar/FACE/UFMG, apoio FAPEMIG, 2004.

MARTINS, Roberto B. Growing in Silence: The Slave Economy of Nineteenth Century Minas Gerais, Brasil. Tese de doutoramento, Venderbil University, USA, 1980.

MARTINS, Roberto B. A Indústria Têxtil Doméstica de Minas Gerais no Século XIX. ANAIS: II Seminário sobre a Economia Mineira. Diamantina: Cedeplar/FACE/UFMG, 1983.

MAX, Karl. O Capital. England: Penguin Books, 1986, vol. 1.

MERRICK, Thomas W; GRAHAM, Douglas H. População e Desenvolvimento Econômico no Brasil. Rio de Janeiro: Zahar, 1981.

27 LIBBY, Douglas Cole. Transformação e Trabalho em uma Economia Escravista, p.198-199.

28 O estudo desta autora sobre a concentração da indústria têxtil, já referido anteriormente (vide nota 14), contraria a tese de Libby segundo a qual a dispersão da indústria têxtil constituiria um elemento "nivelador da sociedade mineira da primeira metade do século passado, pelo menos no que diz respeito "população feminina" (LIBBY, Douglas Cole. Transformação e Trabalho em uma Economia Escravista, p. 198). 
PAIVA, Clotilde A. População e Economia nas Minas Gerais do Século XIX. Tese de doutoramento, Universidade de São Paulo, Departamento de História. São Paulo, 1996.

PAIVA, Clotilde A; MARTINS, Maria do Carmo S. Notas sobre o Censo Brasileiro de 1872. ANAIS: // Seminário sobre a Economia Mineira. Diamantina: Cedeplar/Face/UFMG, 1983.

PAULA, João Antonio de. Dois Ensaios sobre a Gênese da Industrialização em Minas Gerais: A Siderurgia e a Indústria Têxtil. ANAIS: I/ Seminário sobre a Economia Mineira. Diamantina: Cedeplar/FACE/UFMG, 1983.

19. SOUZA, Laura de M. Os Desclassificados do Ouro: A Pobreza Mineira no Século XVIII. Rio de Janeiro: Graal, 1990.

20. VAZ, Alisson M. Cia. Cedro e Cachoeira - História de uma Empresa Familiar: 18831987. Belo Horizonte: Cia. de Fiação e Tecidos Cedro e Cachoeira, 1990.

21. WRIGLEY, E. A. (ed.) Nineteenth-Century Society Essay in the Use of Quantitative Methods for the Study of Social Data. Cambridge at the University Press, 1972.

\section{Fontes Oficiais e Documentais}

22. Censos Industriais e Demográficos do Brasil: Fundação Instituto Brasileiro de Geografia e Estatística - FIBGE/IBGE, Secretaria de Planejamento da Presidência da República.

23. Classificação Brasileira de Ocupações (C.B.O). Ministério do Trabalho — Secretaria de Emprego e Trabalho. Brasília: SPES, 1994 (2a edição).

24. Estatísticas Históricas do Brasil. Séries Econômicas, Demográficas e Sociais - 1550 a 1988. Rio de Janeiro: IBGE, 1990 ( $2^{a}$ ed. revista e atualizada do vol. 3 de Séries Estatísticas Retrospectivas).

25. Listas Nominativas da População de Minas Gerais de 1831-32. Banco de Dados, Cedeplar/UFMG (Núcleo de História Econômica e de Demografia Histórica).

26. "Os Recenseamentos Gerais do Brasil no Século XIX: 1872 e 1890". Centro Brasileiro de Análise e Planejamento - CEBRAP, apoio FAPESP. (Coordenador: Pedro Puntoni, pesquisadora principal: Miriam Dolhnikoff). São Paulo, 2004. 